\title{
Potential effect of Sesame (Sesamum Indicum) seeds and oil on iron deficiency anemia in rats
}

\author{
${ }^{1}$ Rehab Ibrahim Tag Al Deen and ${ }^{2}$ Rania Shams El deen Fakher Eldeen \\ ${ }^{1}$ Home Economics Dept., Faculty of Specific Education, Zagazig University, Egypt. \\ ${ }^{2}$ Home Economics Dept., Faculty of Specific Education, Tanta University .Egypt.
}

\section{Abstract}

$\mathrm{S}$

esame is rich in bioactive food components has therapeutic properties on anemia in rats. The present study aimed to evaluate the effect of sesame seeds and its oil on management of anemia, lipid profile and improve antioxidant

status in animal. This study was conducted on twenty albino male rats and categorized into 4 groups (5 rats per each). Group (1) kept as normal group (control -ve), while the other three groups were administered a single dose of phenyl hydrazine injection 40 $\mathrm{mg} / \mathrm{kg} / \mathrm{day}$ for two days, then rats categorized into three groups which were group 2 control positive (+ve) (untreated) and groups (3and 4) treated with $15 \%$ as a powder of sesame seeds and $5 \mathrm{ml}$ of oil by stomach tube daily for eight weeks, respectively. The obtained results revealed that sesame seed and oil contain highest amount of phenolic compounds and polyunsaturated fatty acids. The biological results showed that significant $(\mathrm{p} \leq 0.05)$ increase in hemoglobin and RBCs were noticed in rats treated with sesame seeds and oil when compared with positive control> Also, significant $(p \leq 0.05)$ increase in total antioxidants (TA), superoxide dismutase (SOD), were observed in rats treated with Sesame seeds and oil than positive control. The results showed that a decrease significantly $(\mathrm{p} \leq 0.05)$ in serum triglyceride, total cholesterol and LDL-c, VLDL-c levels and a significant $(\mathrm{p} \leq 0.05)$ increase in HDL-c level were spotted in rats treated with sesame seed and oil than positive control.

Keywords: Sesame seeds, total phenolic compounds, hemoglobin, antioxidants, nutritional deficiencies.

\section{Introduction}

Anemia is a public health and nutrition problem affecting developing and developed countries, affecting human health and also social and economic development (Means, 2019). Anemia is more prevalent in developing countries with high propagation rates due to nutritional deficiencies. It is other causes of include severe menstrual loss, parasitic contagion, chronic, infections, micronutrient deficiencies, and hemoglobinopathy (kaur et al., 2015). 
Bedigion and Dorthea, (2011) found that 34 species of sesame (Sesamum Indicum ) are found in the world mainly in tropical South Africa and Asia, Nigeria, Sudan, Congo and 8 are species in the Indian region, and must have been cultivated in Euphrates valley and in Bokhara of Afghanistan. Recently, the African origin has also been well established. Chafique and Fleurentin, (1987) and Michalak et al., (2018) reported that it is cultivated throughout the tropical and subtropical regions in India, in South Africa, Asia, Sudan, Afghanistan, Pakistan, Bangladesh, and in many countries.

Nakano et al. (2002) asserted that sesame seeds and oil are consumed as a staple food. Sesame seeds is used in traditional medicine for many diseases treatment. Hall, (2003) and Kuijsten et al. (2005) demonstrated that sesame oil contains of (35:54\%) oleic, (39:59\%) linoleic, (10\%) palmitic acids and bioactive compounds such tocopherols and lignin, which role play important role on antioxidant. Also, Zhenwei et al. (2012) and Erfan Sadeghi et al., (2018) mentioned that, sesame seeds and oil are rich in the essential amino acids. It also contains of minerals $\mathrm{Mg}, \mathrm{Ca}, \mathrm{P}, \mathrm{Fe}$, $\mathrm{Zn}$, and $\mathrm{Co}$, and vitamin $\mathrm{E} \& \mathrm{~K}$ and rich in fiber, carbohydrate and protein.

Regarding healthy aspects, Jannat et al. (2013) and Obiajunwa et al., (2015) reported that, sesame seed and oil have widely used to supply energy and prevent aging and by has a high content of antioxidant known to human health because it contains are $\gamma$-tocopherol and phenols. Also, Wen-Huey et al., (2006) suggested that, sesame intake decreases blood lipids and improve sex hormones in postmenopausal women. Furthermore, Penavalo et al., (2005) investigated that sesame oil has multiple physiological functions which are responsible for its estrogenic activity and also decreasing blood lipids. Recently, Mohamed and Awatif, (2018) recommended that, sesame seed (Sesamum indicum L.) seed and oil used widely as healthy foods to provide nutraceuticals and nutrients that may have an anti-aging effect and increase energy. Also, Ensminger and Esminger, (2017) indicated that, sesame seeds contains calcium which helps to prevent colon cancer, osteoporosis. Also it contains zinc which 
protect of osteoporosis. In this concern, Coony et al. (2001) observed that, sesame seed consumption enhances vitamin $\mathrm{E}$ activity which in turn prevents heart diseases and cancer. Also, Elleuch et al. (2007) stated that, sesame seed contains flavonoid, which used as effective antioxidant and anticancer, and also affects blood lipids and sex hormones. Therefore, the present study aims to investigate the potential effect of sesame seeds and oil on iron deficiency anemia in rats.

\section{Materials and Methods}

\section{Materials}

Sesame seed and oil: were obtained from local markets, El - Mansoura, Egypt.

Rats: Male albino rats $(90 \pm 15 \mathrm{~g})$ were obtained from Helwan Station, Ministry of Health and Population, Cairo, Egypt (Reeves, et al., 1993).

\section{Methods}

\section{Preparation of seeds powder :}

Seeds was milled in a mixer to give a powder and kept in dusky stoppered glass bottles in a dark dry location till use, according to Russo, (2001)

\section{Determination of phenolic compounds}

Total phenolic compounds were determined by HPLC according to the method of Goupy et al., (1999).

\section{Determination of fatty acids}

The fatty acid profile of sesame seed oil was determined according to ISO 5508 (1990) and ISO 5509 (2000) by gas chromatography (GC) as described by Nath, (1996).

\section{Experimental Diets}

The basal diet prepared according to the following formula as mentioned by (AIN, 1993) as follow: corn oil (10\%), protein (10\%), corn starch $(69.5 \%)$, cellulose $(5 \%)$ vitamin mixture $(1 \%)$, mineral mixture 
(4\%), methionine (0.3\%) and choline chloride (0.2\%). Vitamins and minerals mixtures were prepared such as described by Campbell, (1963) and Hegsted, (1941), respectively.

\section{Biological experimental design}

Rats were fed on basal diet adaptation for five days then the rats were allocated into four equal groups. Ethical guidelines were maintained in animal handling during the study and permission was obtained from the concerned Department. Normal control group fed on the basal only $(n=5)$, while the other three groups were administered a single dose of phenyl hydrazine injection $(40 \mathrm{mg} / \mathrm{kg} /$ day) for two day, then rats categorized into three groups which were control positive (+ve) (untreated) and two groups treated with sesame seeds ( $5 \mathrm{~g} / \mathrm{kg}$ diet/day) and oil $(5 \mathrm{ml} / \mathrm{kg} /$ day $)$ by stomaic tube daily. The study assigned for eight weeks. The feed intake was calculated daily and the body weight gain was recorded weekly.

\section{Serum analysis}

At the end of the experiment, the rats were sacrificed to obtain blood samples. Heparenized blood was analyzed for estimation of hemoglobin (HB), red blood cells (RBCs), white blood cells (WBCs) and platelets count (PLT) asses by Drabkin (1949) and Mc Inory, (1954), respectively. Total cholesterol, HDL-cholesterol and triglyceride content were determined by enzymatic colorimetric method according to Allian et al., (1974), Richmond (1973) and Fossati and Principle (1982), respectively. LDL-cholesterol and VLDL-cholesterol were calculated by Friedewald $\boldsymbol{e} \boldsymbol{t}$ al., (1972). Total antioxidants and superoxide dismutase enzymes (SOD) were determined by Beuchamp and Fridovich, (1971) and Green et al., (1981), respectively.

\section{Statistical Analysis}

Results of the biochemical estimations of the rats are reported as mean \pm SE (Standard Error). The total variation was analyzed by performing one-way analysis of variance. "LSD (Least Significant Difference) test" was used for determining significance (Sümbüloglu $\boldsymbol{e t}$ al. 1998). 


\section{Results and Discussion}

\section{The contents of phenolic compounds (ppm) in sesame seed}

Data in Table (1) showed the amounts of phenolic compounds with an average from 0.73 to $2425.16 \mathrm{ppm}$. The sesame seeds content was highest in e-vanillic followed by salycilic, catechein and 3-OH-tyrosol their content were 2425.16, 63.91, 34.52 and $23.37 \mathrm{ppm}$, respectively. While the lowest amounts of phenolic compound in sesame seeds were reversetol, iso-ferulic, gallic, 4-amino-benzoic and content were $0.73,1.17,1.43$ and $2.12 \mathrm{ppm}$, respectively.

These results agreed with the results of Lee et al.., (2002) who observed that epicatechin, procyanidins, guercint and $p$-catechins are flavonoids in sesame seed. Also, Kanu et al., (2007) recommended that, sesame seeds contain of the bioactive compounds that play a role in the reduction of the risk for the development of chronic diseases. Furthermore, Russo, (2007) suggested that, contain of salycilic acid are rich in other phenolic acids and the contribution of these compounds to the protective effect incidence of colorectal cancer.

Table (1): Polyphenolic compounds and flavonoid (ppm) in sesame seed

\begin{tabular}{l|c|c|c}
\hline Phenolic compounds & sesame seed & Phenolic compounds & sesame seed \\
\hline Gallic & 1.43 & Vanillic & 3.06 \\
\hline Pyrogallol & 6.27 & P-conmaric & 3.97 \\
\hline 4-Amino-benzoic & 2.12 & Ferulic & 3.18 \\
\hline 3-OH-Tyrosol & 23.37 & Iso-ferulic & 1.17 \\
\hline Protocatchuic & 6.46 & Reversetol & 0.73 \\
\hline Chlorogenic & 2.56 & Ellagic & 21.11 \\
\hline Epi-Catachin & -- & E-vanillic & 2425.16 \\
\hline Catechein & 34.52 & coumaric -Alpha & 5.80 \\
\hline Catechol & 14.83 & Benzoic & 6.33 \\
\hline Caffeine & 9.67 & $3,4,5$-methoxy- & 5.35 \\
\hline P-Oh-benzoic & 7.97 & cinnamic & 12.11 \\
\hline Caffeic & 4.41 & Salycilic & 63.91 \\
\hline
\end{tabular}




\section{Gas chromatography of sesame oil}

For fatty acid composition, pumpkin seed oil was analyzed by gas chromatography with capillary column in (Table 2). The recorded that ethanolic extract were oleic acid 1 (13.01\%), linoleic acid (33.14\%), 9Eocadecenoic acid $(4.41 \%)$, palmitic acid (3.07\%), 2-furanpentanoic acids $(0.41 \%)$, arachidic acid $(0.28 \%)$, behenic acid $(0.65 \%)$, stearic acid $(9.03 \%)$, docosanoic acid $(0.54 \%)$ and gadoleic acid $(0.31 \%)$ respectively. This data confirms the good nutritional quality with functional properties of sesame oil as our body is unable to synthesize fatty acids.

These results are in accordance with those obtained by Cook and Samman, (1996) who illustrated that, fatty acids are antioxidants, free radical scavengers and inhibit lipid peroxidation. Also, Mazandarani et al., (2012) justified that phenolic compounds are considered as a major group of antioxidant molecules that contribute to the antioxidant activities of seeds and herbs of their ability to scavenge free radicals. Shyu and Hwang, (2002) reported that, the antioxidant activity of sesame seed and its healthful properties are attributed to the presence of lignans such as sesamolin and 2-Episalatin. Agarwal et al. (2005) said that the imbalance of oxidants generates of excessive amounts of reactive oxygen species prejudice in body on various ways. Sabuncu et al. (2001) illustrated that, reproductive cells and tissues will stay stable only when antioxidant and oxidant status is in balance with oxidative stress.

Table (2): Fatty acid composition of sesame seed oil

\begin{tabular}{c|c}
\hline Component & Relative area (\%) \\
\hline Oleic acid & 13.01 \\
\hline Linoleic acid & 33.14 \\
\hline 9E-Ocadecenoic acid & 4.41 \\
\hline Palmitic acids & 3.07 \\
\hline 2-furanpentanoic acids & 0.41 \\
\hline Arachidic acid & 0.28 \\
\hline Behenic acid & 0.65 \\
\hline Stearic acid & 9.03 \\
\hline Docosanoic acid & 0.54 \\
\hline Gadoleic acid & 0.31 \\
\hline
\end{tabular}




\section{Effects of sesame seed and oil on BWG, FI and FER of experimental rats}

Data in Table (3) showed that an significant increase in the body weight gain (BWG), food intake (FI) and food efficiency ratio (FER) of all rat groups treated with red beet than positive control. The results showed that an increase significantly in BWG was noticed of rats group treated with sesame seed which reached $63.43 .0(\mathrm{~g})$ and rats group treated with sesame oil which reached $66.65(\mathrm{~g})$ than positive control which reached 41.88 (g). Also the results revealed that an increase significantly in FI was recorded of rats group treated with sesame seeds which reached 15.99 (g/day) and rats group treated with sesame oil which reached 16.21 (g/day) when compared with positive control which reached 11.73(g/day). On the same table, the results showed that significant increase in FER was observed of rats groups treated with sesame seeds and oil which reached 0.065 and 0.074 respectively than positive control which reached 0.059 . Díaz-Castro et al. 2008 reported that the body weights of the anemic rats were significantly lower.

Table (3): Effect of sesame seed and oil on BWG, FI and FER of experimental rats

\begin{tabular}{ccccc}
\hline Parameters & Negative control & Positive control & Sesame seed & Sesame oil \\
\hline B W G (g) & $95.72 \pm 8.42^{\mathrm{a}}$ & $41.88 \pm 5.1^{\mathrm{d}}$ & $63.43 .0 \pm 6.13^{\mathrm{c}}$ & $66.65 \pm 5.57^{\mathrm{c}}$ \\
F I (g/day) & $16.85 \pm 1.84^{\mathrm{a}}$ & $11.73 \pm 1.17^{\mathrm{c}}$ & $15.99 \pm 1.45^{\mathrm{b}}$ & $16.21 \pm 1.22^{\mathrm{a}}$ \\
FER & $0.0894 \pm 0.001^{\mathrm{a}}$ & $0.059 \pm 0.003^{\mathrm{d}}$ & $0.065 \pm 0.005^{\mathrm{c}}$ & $0.074 \pm 0.004^{\mathrm{b}}$ \\
\hline
\end{tabular}

Means in the same row with different superscript letters are significantly different at $\mathrm{P} \leq 0.05$.

\section{Effects of sesame seed and oil on hemoglobin, RBCs, WBCs and PLT of experimental rats}

As evident from Table (4) a significant $(\mathrm{P}<0.05)$ increase in hemoglobin, red blood cells (RBCs) and significant decrease in white blood cells (WBCs) and platelets count (PLT) of all rat groups treated with sesame seeds and oil than positive control. The results showed that significant increase in hemoglobin was noticed of rats groups treated with 
sesame seeds and oil which reached (10.9 and 11.7) respectively than positive control which reached (7.77).

Table (4): Effect of sesame seed and oil on hemoglobin, RBCs, WBCs and PLT of experimental rats

\begin{tabular}{ccccc}
\hline Parameters & $\begin{array}{c}\text { Negative } \\
\text { control }\end{array}$ & Positive control & Sesame seeds & Sesame oil \\
\hline Hemoglobin & $12.12 \pm 1.2^{\mathrm{a}}$ & $7.77 \pm 0.22^{\mathrm{d}}$ & $10.9 \pm 0.3^{\mathrm{c}}$ & $11.7 \pm 2.4^{\mathrm{b}}$ \\
\hline RBCs & $6.4 \pm 0.21^{\mathrm{b}}$ & $2.58 \pm 0.2^{\mathrm{e}}$ & $4.7 \pm 1.1^{\mathrm{d}}$ & $4.9 \pm 0.9^{\mathrm{d}}$ \\
\hline WBCs & $4.4 \pm 1.4^{\mathrm{c}}$ & $7.6 \pm 1.3^{\mathrm{a}}$ & $5.8 \pm 0.2^{\mathrm{b}}$ & $4.85 \pm 0.3^{\mathrm{c}}$ \\
\hline PLT & $293 \pm 16.8^{\mathrm{f}}$ & $391 \pm 7.4^{\mathrm{a}}$ & $317 \pm 8.3^{\mathrm{e}}$ & $336.25 \pm 18.4^{\mathrm{d}}$ \\
\hline
\end{tabular}

Means in the same row with different superscript letters are significantly different at $\mathrm{P} \leq 0.05$.

Also the results showed that significant increase in RBCs was noticed of rats groups treated with sesame seeds and oil which reached (4.7 and 4.9) respectively when compared with positive control which reached 2.58 On the other hand, the results recorded that a significant decrease in WBCs and PLT was noticed of rats groups treated with sesame seeds which reached (5.8 and 317) respectively, and rats groups treated with sesame oil which reached (4.85 and 336.25) respectively, than positive control which reached (7.6 and 391) respectively. These results advised that, it is important to give sesame seeds and oil to patients suffering from anemia. These results are accordance with that of (Benkovic et al., 2009) who showed that Sesame seeds mainly stimulates the factors related to RBCs rather than WBCs.

\section{Effects of sesame seed and oil on some antioxidant parameters of experimental rats}

Data in Table (5) revealed significant increase in total antioxidants (TA), superoxide dismutase (SOD) was observed in rats group treated with sesame seeds and oil than positive control. The results explained that an increase significantly in TA was observed of rats group treated with sesame seeds which reached $3.5 \mathrm{mmol} / \mathrm{L}$ and rats group treated with sesame oil which reached $3.9 \mathrm{mmol} / \mathrm{L}$ when compared with positive control which reached $1.3 \mathrm{mmol} / \mathrm{L}$. Also the results showed that an significant increase in SOD was recorded of rats group treated with red beet $2 \mathrm{ml}$ which reached 
$(54.14 \pm 7.16 \mathrm{U} / \mathrm{Ml})$ and rats group treated with Sesame seeds which reached $(60.8 \mathrm{U} / \mathrm{Ml})$ when compared with positive control which reached (20.0U/Ml).

These results agreed with the results of Kanu et al. (2007) recommended that, sesame seeds contained bioactive compounds that play a role in the reduction of the risk for the development of chronic diseases. Russo, (2007) suggested that, contain of salycilic acid are the contribution of these compounds to the protective effect incidence of cancer.

Table (5): Effects of sesame seed and oil on some antioxidant parameters of experimental rats

\begin{tabular}{ccccc}
\hline Parameters & $\begin{array}{c}\text { Negative } \\
\text { control }\end{array}$ & $\begin{array}{c}\text { Positive } \\
\text { control }\end{array}$ & Sesame seed & Sesame oil \\
\hline $\begin{array}{c}\text { Total antioxidants } \\
\text { mmol/L }\end{array}$ & $4.55 \pm 0.22 \mathrm{a}$ & $1.3 \pm 0.15 \mathrm{c}$ & $3.5 \pm 0.15 \mathrm{~b}$ & $3.94 \pm 0.06 \mathrm{~b}$ \\
$\begin{array}{c}\text { Superoxide dismutase } \\
\text { (U/MI) }\end{array}$ & $65.13 \pm 5.22 \mathrm{a}$ & $20.0 \pm 3.47 \mathrm{~d}$ & $55.14 \pm 7.16 \mathrm{c}$ & $60.87 \pm 6.35 \mathrm{~b}$ \\
\hline & & & & \\
\hline Means in the same row with different superscript letters are significantly different at $\mathrm{P}<0.05$
\end{tabular}

Means in the same row with different superscript letters are significantly different at $\mathrm{P} \leq 0.05$.

\section{Effects of sesame seeds and oil on lipid parameters of experimental rats.}

The results in Table (6) showed that a decrease significantly in serum triglyceride, total cholesterol and LDL-c, VLDL-c levels and a significant increase in HDL-c level were observed in rats treated with Sesame seeds and oil than positive control. Data presented showed a significant decrease in total cholesterol of rats treated with Sesame seeds reached $(115.67 \mathrm{mg} / \mathrm{dl})$ and rats treated with Sesame oil reached $(98.80 \mathrm{mg} / \mathrm{dl})$ when compared with positive control which reached $(130.5 \mathrm{mg} / \mathrm{dl})$. Also the results showed a significant decrease in triglyceride of rats treated with Sesame seeds and oil which reached $(90.5$ and $75.3 \mathrm{mg} / \mathrm{dl})$ respectively when compared with positive control which reached $(100.13 \mathrm{mg} / \mathrm{dl})$. On the other hand, the results showed an increase significantly in HDL-c of rats treated with Sesame seeds and oil which reached (33.15 and $33.53 \mathrm{mg} / \mathrm{dl})$ when compared with positive control which reached $(28.23 \mathrm{mg} / \mathrm{dl})$.

The results showed decrease significantly in LDL-c was observed of rats treated with sesame seeds which reached $(60.58 \mathrm{mg} / \mathrm{dl})$ and rats treated 
with Sesame oil which reached $(48.37 \mathrm{mg} / \mathrm{dl})$ when compared with positive control $(78.87 \mathrm{mg} / \mathrm{dl})$. These results agreed with Barbosa et al.. (1998) who explained that, feeding rats on sesame seed resulted decrease in lipid level, and increase of tocopherol levels in blood and liver. Arts et al., (2001) found that, there was a strong inverse association between the intake of catechin and coronary heart disease. Moghaddam et al. (2016) reported that, the proanthocyanidin content of sesame was able to reduce TG levels.

Table (6): Effects of sesame seeds and oil on lipid parameters of experimental rats

\begin{tabular}{lcccc}
\hline \multicolumn{1}{c}{ Parameters } & $\begin{array}{c}\text { Negative } \\
\text { control }\end{array}$ & Positive control & Sesame seed & Sesame oil \\
& $82.27 \pm 4.16^{\mathrm{d}}$ & $130.57 \pm 4.71^{\mathrm{a}}$ & $115.67 \pm 7.26^{\mathrm{b}}$ & $98.80 \pm 2.44^{\mathrm{c}}$ \\
\hline TC (mg/dl) & $68.13 \pm 2.97^{\mathrm{d}}$ & $100.13 \pm 2.97^{\mathrm{d}}$ & $90.5 \pm 3.14^{\mathrm{b}}$ & $75.3 \pm 5.22 \mathrm{~b}^{\mathrm{c}}$ \\
TG (mg/dl) & $39.50 \pm 2.29^{\mathrm{a}}$ & $28.23 \pm 1.37^{\mathrm{c}}$ & $33.15 \pm 1.76^{\mathrm{b}}$ & $33.53 \pm 3.02^{\mathrm{b}}$ \\
HDL-c (mg/dl) & $29.14 \pm 5.99^{\mathrm{e}}$ & $78.87 \pm 3.55^{\mathrm{a}}$ & $60.58 \pm 5.76^{\mathrm{b}}$ & $48.37 \pm 1.34^{\mathrm{c}}$ \\
LDL-c (mg/dl) & $20.06 \pm 2.13^{\mathrm{a}}$ & $18.1 \pm 0.63^{\mathrm{b}}$ & $15.08 \pm 1.04 \mathrm{~b}^{\mathrm{c}}$ \\
\hline VLDL-c (mg/dl) & $13.63 \pm 0.59^{\mathrm{d}}$ & 20.05. \\
\hline
\end{tabular}

Means in the same row with different superscript letters are significantly different at $\mathrm{P} \leq 0.05$.

\section{Conclusion}

This study has revealed that sesame seed and oil is an important source of many healthy components such as polyunsaturated fatty acids, phenolic phytochemicals in sesame seed and oil makes it an excellent source of bioactive components which may provide potential protection against anemia. Further researches with purified constituents are recommended to better understanding of the complete mechanism of sesame seed and oil in hemoglobin, RBCs, WBCs , and PLT levels in blood and oxidative enzymes. Sesame seeds and oil improve anemia and affects cardiovascular system.

\section{References}

Allian, C.A. , Poon, S., Chan, C. S. G. Richmond, W. and Fu, P.C.1974. Enzymatic determination of total serum cholesterol. Clinical Chemistry, 20:470-475. 
AIN. American Institute of Nutrition. 1993. Purified diet for laboratory Rodent, Final report. J. Nutrition. 123:1939-1951.

A O A C., 2000. Association of Official Agricultural Chemists. Official Method of Analysis. $17^{\text {th }}$ Ed., Washington DC.

Benkovic V, Knezevic AH, Orsolic N, Basic I, Ramic S, Viculin T, Knezevic F, Kopjar N. 2009. Evaluation of radioprotective effects of propolis and its flavonoid constituents: in vitro study on human white blood cells. Phytother Res. 23:1159-1168.

Beuchamp, C. and J. Fridovich 1971. Superoxide dismutase. Improved assay an assyapplicable to acryloamide gels. Anal Biochem. 44: 276-287.

Campbell, J. A. 1963. Methodology of protein evaluation. RGA Nutr. Document R. Led. 37. June meeting, New York .

Chafique, Y. and Fleurentin, J. (1987): Repertory of drugs and medicinal plants used in traditional medicine of Afghanistan. J. of Ethnopharmacology., 20: 245-290.

Coony, R.V.; Custer L.J.; Okinaka, L. and Franke, A.A. (2001): Effect of dietary sesame seeds on plasma ticopherol levels. Nutr Cancer., 39: $66-71$.

Díaz-Castro J, Alférez MJM, López-Aliaga I, Nestares T, Granados S, Barrionuevo M, Campos MS, 2008. Influence of nutritional iron deficiency anemia on DNA stability and lipid peroxidation in rats. Nutrition, 24:1167-1173.

Drabkin, D., 1949. The standardization of hemoglobin measurements. Am. J. Med. Sci., 21 (7): 710.

Elleuch, M.; Besbes, S.; Roiseux, O.; Blecker, C. and Attia, H. (2007): Quality characteristics of sesame seeds and by-products. J. of Food Chemistry, 103(2): 641-650.

Erfan Sadeghi, Zohreh Ghotbeddin and Godratollah Mohammadi 2018. The effects of Sesame seeds on the pituitary-gonadal axis in adult male rats Discover the world's research 580-588. 
Ensminger A.H. and Esminger M. K. J. (2017): Food for health: A nutrition encyclopedia. Clovis, California: Pegus Press, PMID: 15210.

Fossati, P. and Principle, L. 1982. Estimation of the concentration of triglyceride in plasma and liver. Clinical Chemistry 28: 20772081.

Friedewald and Fredrickson, D. S. 1972. Estimation of the plasma low density lipoprotein cholesterol without use of the preparative ultracentrifuge. Clinical Chemistry,18:499- 502.

Goupy, P: Hugues M., Boivin, P and Amiot, j. 1999. Antioxidant composition and activity of barley (Hordeum vulgare) and malt extract and of isolated phenolic compounds. J.Sci. Food Agric.79: 1625-1634.

Green, L.C.; Wagner, D.A.; Glokowski, J.; Skipper, P.L.; Wishnok, J.S. and Tannenbaum, S.R. 1981. Analysis of nitrite, nitrate, and [15N] nitrite in biological fluids. Anal. Biochem1., 126: 131-138.

Hegsted, D.; Mills, R. and Perkins, E. 1941. Salt mixture .J. Biol. Chem, 138:459.

Jannat, B.; Oveisi, M.R.; Sadeghi, N.; Hajimahmoodi, M.; Behzad, M.; Nahavandi, B.; Tehrani, S.; Sadeghi, F. and Oveisic, M. 2013. Effect of roasting process on total phenolic compounds and $\gamma$-tocopherol contents of iranian sesame seeds (Sesamum indicum). Iran J. of Pharm Res., 12(4): 751-758.

Kuijsten, A.; Arts, I.C. and Hollman, P.C. 2005. The relative bioavailability of enterolignans in humans is enhanced by milling and crushing of flaxseed. J. of Nutr., 135(12), 28122816.

Mc Inory, 1. 1954: Amicro heamatocrit for determining the packed cell and hemoglobin concentration on capillary blood. J. Clin., Path., (7): 32 . 
Means R.T. 2019. The Anemia of Inflammation/Chronic Disease and the Unexplained Anemia of the Elderly. In: Means Jr. R. (eds), 319:4-9

Mohamed, H.M.A. and Awatif, I.I. 2018. The use of sesame oil unsaponifiable matter as natural antioxidant. J. of Food Chem., 62: 269-276.

Nath M, S. C.; Pathak, M. G. and Baruah, A. 1996. Benzyle benzoate, the major component of leaf and steam bark oil Cennamoumum zelyanicum blum. J. Esent. Oil Res. 8: 327 - 331.

Obiajunwa, E.I.; Adebiyi, F.M. and Omode P.E. 2015. Determination of essential minerals and trace elements in nigerian sesame seeds, using TXRF technique. Pakistan J. of Nutrition., 4 (6): 393-395.

Penavalo, J.L.; Heinonen, S.M. and Aura, A.M. 2005:. Dietary sesame is converted to enterolactone in humans. J. of Nutr., 135: 10561062

Reeves, P.G., F.H. Nielsen and G.G. Fahmy, 1993. AIN-93. Purified diet for laboratory rodents. Final Report of the American Institute of Nutrition Adhoc Wriling Committee on the reformulation of the AIN-76 A Rodent Diet. J. Nutrition, 123: 1939-51.

Richmond, W. 1973. Estimation of free and etherified tissue cholesterol. Clinical Chemistry 19: 1350- 1354.

Russo, E.B. 2001. Handbook of psychotropic herbs: A scientific analysis of herbal remedies for psychiatric conditions. Binghamton, NY: The Haworth Herbal Press, Inc., 3-24.

Sümbüloglu K, Sümbüloglu V, and Biyoistatistik, 1998. 8thedition, Hatiboglu Yayinevi, Ankara, pp. 76-86.

Wen-Huey, W.;Wen Huey; Yu-Ping, K.; Nai-Hung, W.; Hei-Jen, J. and Tzong-An W. 2006. Sesame ingestion affects sex hormones, antioxidant status, and blood lipids in postmenopausal women. J. of Nutrition., 136(5): 1270-1275. 
Zhenwei, Q.; Yongbing, Z.; Dorthea, B.; Xiao, L.; Chansui, W. and Hongen, J. 2012. Sesame utilization in china: Newchaeobotanical evidence from xinjiang, Econ. Botany., 66(3):255-263.

Kaur M, Singh A, Bassi $R$ and Kaur, H. 2015. Nutritional status and anaemia in medical students of Sgrdimsar, Amritsar. National Journal of Physiology, Pharmacy \& Pharmacology. 5(1):35-49. 


\section{Rehab Tag Al Deen \& Rania Shams El deen}

التأثير المحتمل لبذور وزيت السمسم على فقر الدم الناتج عن نقص الحديد في الفئران

1 ريحاب ابراهيم تاج الدين ، رُانيا شمس الدين فخر الدين

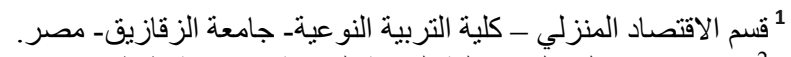

2قسم الاقتصاد المنزلي - كلية التربية النوعية - جامعة طنطا - مصر.

المستخلص

يحتوى السمسم على نسبة عالية من المركبات الغذائية النشطة بيولوجيا والتى يمكن ان يكون خصائص علاجية على فقر الدم لاى الفئران. لذا تهدف الدراسة الحالية إلى نقييم التأثثر المحتمل لبذور وزيت السمسم لعلاج الانيميا الناتج عن نقص الحديد ومستوى الدهون الكلية لهنية

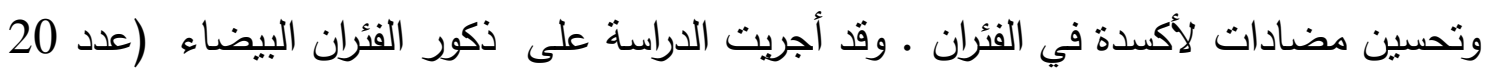

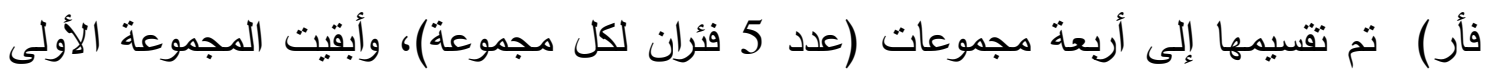
كمجموعة ضابطة سالبة في حين تم حقن المجموعات الثلاث الأخرى بجرعة واحدة من فينهيل هيدرازين (40 ميلليجرام لكل كيلوجرام من وزن الجسم/ يوم) لمدة يومين لاحداث الانيميا ، وابقيت

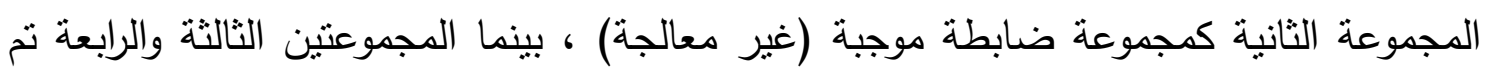
معالجتها بنسبة 15٪ من مسحوق بذور السمسم ، 5 مل زيت السمسم بواسطة أنبوب المعدة يوميًا

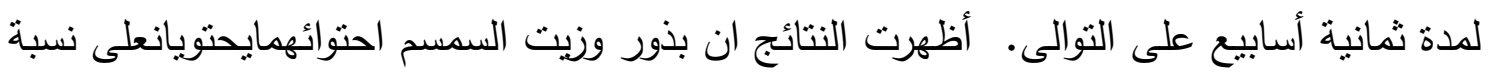

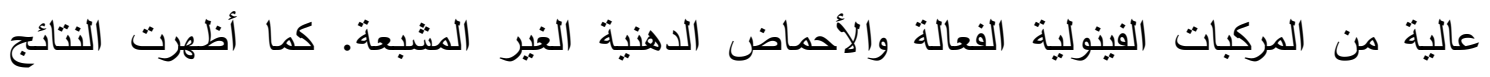
البيولوجية أن هناك ارتفاع ملحوظ في نسبة الهيموجلوبين وكرات الدم الحمراء في الفئران التي لئي

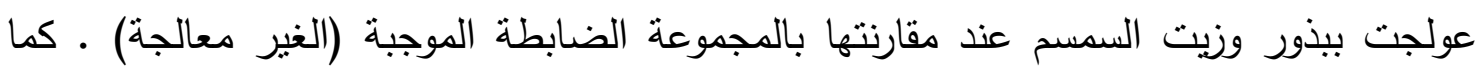

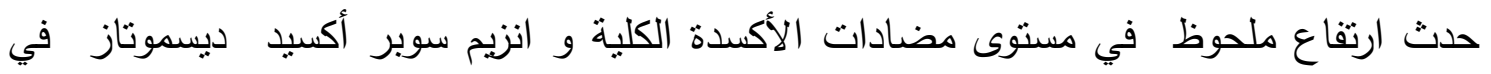

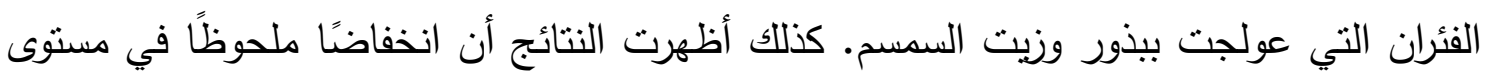

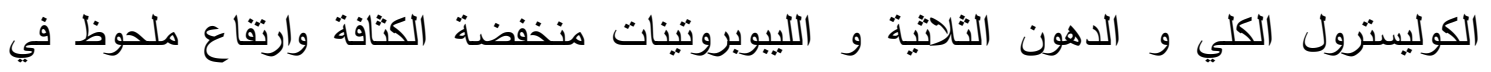

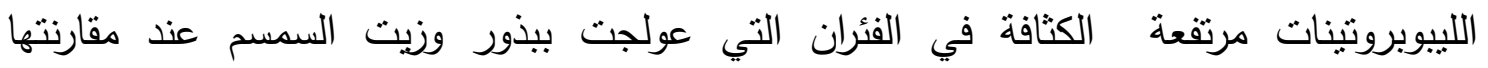

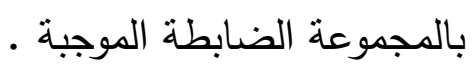
الكلمات المفتاحية: بذور السمسم، الفينولات الكلية، الهيموجلوبين، مضادات الأكسدة النقص

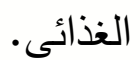

